\title{
Effect of Quackery on Estate Agency Practice in Akure
}

\author{
O.S Adebisi C.A. Adu
}

Department of Estate Management, Joseph Ayo Babalola University, Ikeji Arakeji, Osun-State

\begin{abstract}
This research analysed the effect of quackery and factors that contribute to quackery in estate agency practice in Akure. The data for the study was collected through questionnaires administered on twenty (20) registered Practicing Estate Surveyors and Valuers in Akure. A total of fifteen (15) questionnaires were retrieved and analysed. The data collected were analyzed using Descriptive Statistics (Weighted Mean Scores and Frequency Table). The study revealed that estate agency generated the bulk of income made by Estate firms in Akure. The study also revealed that factors such as free entry of quacks in the practice of estate agency and clients' ignorance contributed to quackery in the practice of estate agency. It further revealed that quackery undermined the positive impact of Estate Surveyors and Valuers in real estate practice and hence a foreseeable extinction of the relevance of Estate Surveyors and Valuers in estate agency practices, if it is not checked. The study therefore recommended that all stakeholders in real estate and the public at large must be continuously educated through conferences, seminars on the practice of Estate Surveying and Valuation Profession and the inherent dangers quackery contributes to the practice of estate agency. Also, though it may be difficult but ESVARBON must develop a strong will to regulate the practice of estate agency in Nigeria.
\end{abstract}

Keywords: Quackery, Charlatan and Estate Agency

DOI: $10.7176 / \mathrm{EJBM} / 11-15-14$

Publication date:May $31^{\text {st }} 2019$

\section{Introduction}

Agency is the creation of a contract entered into by mutual consent between a principal and an agent. By agency, a principal grants authority to an agent to act on behalf of and under the control of the principal. Such relationship could be established when principals are convinced that the involvement of agents will produce more effective returns usually due to their vintage in training, commitment and conversance in the prescribed endeavor. Its application is in various spheres of life. However, in real estate practice, where the market is lacking in information, the role of an estate agent cannot be overemphasized. Estate agency is the act of liaising between two parties to bring about the transfer of an interest in landed property either by outright assignment or the creation of an interest in the form of a lease or term of years (Akomolede, 2006). Estate Agency is one of the most lucrative aspects of Estate Surveying and Valuation practice as it produces good income (Idudu, 2014). It may be pejorative to refer to Estate Surveyors as 'estate agents' but many estate firms are sustained by the income from estate agency. Estate agency which comprises of purchases, sales and lettings is keenly competed for by all other professionals - lawyers, doctors, engineers, accountants, teachers, unemployed and all manner of people (Idudu, 2014).

Professionals have continued to criticize the involvement of charlatans in estate agency by pinpointing the negative effects their activities (Quackery) constitute to the society which include but not limited to arbitrary rent increase, non-remittance of rents to property owners, abnormal charges on prospective tenants (Idudu, 2014). Idudu, (2014) further stated that in spite of clear declarations as regards the practice of estate agency, Estate 
Surveyors and Valuers have not been able to exclude non-Estate Surveyors and Valuers (Charlatans) from its practice. Nemieboka, (2010) while commenting on the negative implications of the involvement of quacks in the housing sector in Nigeria disclosed that there is no legislation outlawing quacks from agency in the country. "It is an all comers affair as it were and anybody can go to the Corporate Affairs Commission and say that he is a property agent, the commission will register the person" he revealed.

However, the Solanke (2010)'s Mathematical Model for Professional Survival sighted in Oni and Adebayo (2012) has become an issue of great concern. The model predicts the period within which profession of Architecture, Estate management, and Building construction would lose their relevance in Nigeria. It predicts if the present situation does not change, Estate Management would lose relevance within the next 21 years. The path towards sustainable real estate practice most especially agency in Nigeria has being facing a lot of challenges and efforts must be geared at solving them if the predictions must be averted, hence the need for the study.

\section{Literature Review}

Estate agency practice covers a very wide field - houses, factories, shops, offices, hotels, farms and land. It covers the disposal by way of sale, letting of residential, commercial, industrial and agricultural property.

One would not deny the ability of an average house owner to let/dispose of his own house. Many do so, but the reasons why the majority choose to use the services of Estate Surveyors and Valuers are matters involving knowledge of building construction, property market, planning blight and remedies open to client affected, basic compensation rules, town planning rules, rent control edict, estate duty, capital gains tax, development levy and others on which he should be well informed (Idudu 2014). In Estate Agency, an agent doesn't provide a competent service without a basic knowledge of the principles of valuation, property market operations and law as it applies to the field.

In Nigeria, Section 25 and 26 of Decree 24 of 1975 empowers the Estate Surveyor and Valuer in carrying out operations as an estate agent. The organized body recognized for the regulation of practice is the Estate Surveyors and valuers Registration Board of Nigeria (ESVARBON). However, the Corporate Affairs Commission (CAC), body statutorily empowered for registration of every business outfit in the country, regards estate agency as a business concern and classifies it under general business practice (Akomolede, 2006; Oni, 2009). This has partly accounted for why non-professionals engage in estate agency. The agency practice is regarded as an all comers' affairs as lawyers, engineers, accountants and even laymen learned in numeric details carry out this operation (Iroham, Olawumi, Ayedun and Oloyede, 2011). An expression has become synonymous with the estate surveying profession calling every other profession dabbling into agency as quacks. However, there are no clear cut-out edicts granting the estate surveyor and valuer the exclusive preserve of operation even when series of protest has been made to that effect (Iroham, Olawumi, Ayedun and Oloyede, 2011). Akomolede (2006) and Oni (2010) corroborated this by stating that the challenges facing estate agency and brokerage practice in Nigeria are numerous, among which competition from quacks is most widespread. Estate agency is characterized but not limited with acts such as gazumping and gazundering (Akomolede, 2006). Oni (2009) further stated that these acts are prevalent amongst non-professionals (charlatans/quacks) and only negligible few professionals are involved. Observation reveals that this is as a result of concerted efforts made by the Nigerian Institution of Estate Surveyors and Valuers (NIESV) and the Estate Surveyors and Valuers Registration Board of Nigeria (ESVARBON) to drive 
professionalism, honesty and devotion.

The activities of charlatans (otherwise known as quacks) have posed great threat to sustainable real estate practice in Nigeria. They are unregulated and do not belong to any professional body that regulate their operations. Oni (2010) stated that the reasons for high rate of quackery are not farfetched; other professionals like Lawyers and Architects have dabbled into estate agency through their first contact opportunities with property owners, while many others that are not literate have stepped in as result of increasing rate of unemployment in Nigeria. Akomolede (2006) also stated that the relative lucrativeness of estate agency in Nigeria coupled with the lack of will by the ESVARBON to curb excesses by regulating the practice of estate agency has created the loop hole for the exploits of quack dispositions in Nigeria's real estate agency sector. This study intends to justify the dire need ESVARBON must develop a strong will to regulate the practice of estate agency

\section{Methodology}

The data for the study was collected from practicing Estate Surveyors and Valuers in Akure. Adebisi, Ezeokoli, Oletubo and Alade (2015) stated that there are Twenty (20) practicing Estate Surveyors and Valuers according to the list of registered and practicing Estate Surveyors and Valuers in Akure obtained from the Secretariat of The Nigerian Institution of Estate Surveyors and Valuers (NIESV), Ondo State Branch. This constitutes the sample frame which was also adopted as the sample size as suggested by Israel (2002) for small population of 200 or less. However, out of the twenty (20) Estate Surveyors and Valuers, only fifteen (15) responded, this represents $75 \%$ of the sample size. Descriptive Statistics such as Weighted Mean Scores and Frequency Table were used to analyze the data collected. The Weighted Mean Score was used to identify the factors that contribute to quackery in the practice of Estate Agency and consequences of quackery in Estate Agency practice. Frequency Table was used to analyze the percentage of income generated from estate agency for each of the firms.

\section{Data Analysis and Discussion of Results}

This section of the study presents analysis of data collected from the study area and the discussion of results. The analysis was structured to examine the percentage of income realized from estate agency by Estate firms, factors that contribute to quackery in the practice of estate agency, consequences of quackery in estate agency practice.

TABLE 1: The Percentage of Estate Agency Component of Firm's Yearly Income

\begin{tabular}{lcc}
\hline PERCENTAGE OF INCOME & Frequency & Firms (\%) \\
\hline 40 and below & 1 & 6.7 \\
$41-50$ & 3 & 20.0 \\
$51-60$ & 5 & 33.3 \\
$61-70$ & 3 & 20.0 \\
71 and above & 3 & 20.0 \\
Total & 15 & 100.0 \\
\hline
\end{tabular}

SOURCE: FIELD SURVEY, 2017

Table 1 reveals that $73.3 \%$ (11 Firms) of the respondents earn over half of their income from estate agency 
while $6.7 \%$ (1 Firm) of the respondents earn less than $40 \%$ of its income from estate agency. This is in conformity with Idudu (2014) statement that Estate Agency is one of the most lucrative aspects of Estate Management practice as it produces good income. The lucrativeness of estate agency practice has made it an all comer affairs, as it is seen as an avenue by other professionals and laymen to make quick money without necessarily considering the minimum standards to be observed.

TABLE 2: Factors that Contribute to Quackery in Estate Agency Practice in Akure

\begin{tabular}{lccccccc}
\hline Factors & SA (5) & A (4) & U (3) & D (2) & SD (1) & WMS & RANK \\
\hline Free entry of quacks in the practice of Estate & 50 & 20 & 0 & 0 & 0 & 4.6 & 1 \\
Agency & & & & & & & \\
Prying on clients ignorance & 40 & 24 & 3 & 0 & 0 & 4.4 & 2 \\
Preposterous posing of cost incentive in & 10 & 32 & 12 & 2 & 0 & 3.7 & 3 \\
consulting quacks & & & & & & & \\
High Mobility of quacks & 5 & 32 & 9 & 6 & 0 & 3.4 & 4 \\
\hline
\end{tabular}

SOURCE: FIELD SURVEY, 2017

(SA = Strongly Agreed, A = Agreed, U = Undecided, D = Disagreed, SD = Strongly Disagreed)

The result presented in Table 2 indicates that all the factors mentioned contribute to quackery. However, free entry of quacks in the practice of estate agency ranked first with mean score of 4.6. This finding corroborates the findings of Oni and Adebayo (2012) which found out that there is no law regulating the practice of estate agency in Nigeria; hence, it is an all comer affairs. Furthermore, prying on clients' ignorance, preposterous posing of cost incentive in consulting quacks and high mobility of quacks ranked second, third and fourth with mean scores of 4.4, 3.7 and 3.4 respectively.

TABLE 3: Respondents' Opinions on the Prevalence of the Activities of Quacks

\begin{tabular}{lccccccc}
\hline Nature of activity & VO (5) & O (4) & SO (3) & NO (2) & NA (1) & WMS & RANK \\
\hline Collection of double fee & 60 & 12 & 0 & 0 & 0 & 4.8 & 1 \\
Topping up of rent & 50 & 20 & 0 & 0 & 0 & 4.6 & 2 \\
Gazumping & 35 & 20 & 9 & 0 & 0 & 4.2 & 3 \\
Partial/Non-remittance of rent to & 15 & 16 & 24 & 0 & 0 & 3.6 & 4 \\
the landlord & & & & & & & \\
Gazundering & & 5 & & 15 & 16 & 0 & 2.2 \\
\hline
\end{tabular}

\section{SOURCE: FIELD SURVEY, 2017}

$($ VO $=$ Very Often, $O=$ Often, $S O=$ Somewhat Often, $N O=$ Not Often, $N A=$ Not at all $)$

As indicated in Table 3, collection of double fee ranked first with a mean score of 4.8 while topping up of rent, gazumping, partial/non-remittance of rent to the landlord and gazundering ranked second, third, fourth and fifth with mean scores of 4.6, 4.2, 3.6 and 2.2 respectively. 
TABLE 4: The Consequences of Quackery in Estate Agency Practice

\begin{tabular}{|c|c|c|c|c|c|c|c|}
\hline Consequences & $\begin{array}{l}\text { SA } \\
\text { (5) }\end{array}$ & $\begin{array}{l}\text { A( } \\
4)\end{array}$ & $\begin{array}{l}\mathrm{U}( \\
3)\end{array}$ & $\begin{array}{l}D( \\
2)\end{array}$ & $\begin{array}{l}\text { SD } \\
\text { (1) }\end{array}$ & $\begin{array}{l}\text { WM } \\
\text { S }\end{array}$ & $\begin{array}{l}\text { RA } \\
\text { NK }\end{array}$ \\
\hline Undermining of the positive impacts of the professional estate & & & & & & 4. & \\
\hline surveyor and valuer in real estate practice. & 30 & 12 & 18 & 0 & 0 & 0 & 1 \\
\hline Extinction of the relevance of the estate professional in real estate & & & & & & 3. & \\
\hline agency. & 10 & 8 & 24 & 4 & 1 & 1 & 2 \\
\hline Submission of the estate professional to the whims and caprices of & & & & & & 2. & \\
\hline the quacks. & 5 & 16 & 18 & 2 & 3 & 9 & 3 \\
\hline
\end{tabular}

SOURCE: FIELD SURVEY, 2017

(SA = Strongly Agreed, A = Agreed, U = Undecided, D = Disagreed, SD = Strongly Disagreed)

Table 4 shows that undermining of the positive impacts of professional Estate Surveyor and Valuer in real estate practice ranked first with mean score of 4.0 while extinction of the relevance of Practicing Estate Surveyors and Valuers ranked second with mean score of 3.1 as quite a number of the populace are of the opinion that agents (charlatans) are same as Estate Surveyors and Valuers. This makes it difficult to separate Estate Surveyors and Valuers from the unprofessional/unethical activities of the quacks which include but not limited to topping up of rent/price, non-remittance of rent to landlords, gazundering and gazumping. This may lead to Estate Surveyors and Valuers loosing relevance in the practice of estate agency in the nearest future as predicted by Solanke (2010)'s Mathematical Model for Professional Survival.

\section{Conclusion and Recommendation}

This paper has examined the effect of quackery on the practice of estate agency in Akure. It revealed that estate agency produced the bulk of income generated by Estate firms in Akure. It also found out that factors such as free and easy entry of quacks in the practice of estate agency and clients' ignorance significantly contributed to quackery in the practice of estate agency. The paper also found out that undermining of the positive impact of Estate Surveyors and Valuers in real estate practice, foreseeable extinction of the relevance of Estate Surveyors and Valuers in estate agency practice amongst others were direct consequences of the effect of quackery on estate agency practice. Therefore, the public including all stakeholders in real estate must be continuously educated through conferences, seminars etc. on the practice of Estate Surveying and Valuation Profession and the inherent dangers quackery contributes to the practice of estate agency. Also, ESVARBON must develop a strong will to regulate the practice of estate agency in Nigeria.

\section{REFERENCES}

Adebisi, O.S., Ezeokoli, N.B., Oletubo, A.A., and Alade, T.J. (2015). Rental Analysis of Residential Properties in Close Proximity to the Federal University of Technology, Akure, Nigeria. Journal of Economics and Sustainable Development, 6(10), 140-147

Akomolede, K. (2006). Estate Agency Practice in Nigeria. Lagos: Bamboo Books.

Idudu, O.J.A. (2014). Estate Agency, have we lost it? A discourse on the occasion of 20th Annual J.W. Ekpenyong 
Memorial Lecture, Lagos. $11^{\text {th }}$ of June, 2014

Iroham, C.O., Olawumi, A.O., Ayedun C.A., and Oloyede S.A. (2011). An Investigation of the Effeciency in Nigeria Real Estate Practice. Mediterranean Journal of Social Sciences, 2(2), 184-193

Israel, G.D. (2002). Sampling the Evidence of Extension Program Impact. Program Evaluation and Organizational Development, IFAS, University of Florida.

Oni, A.O. and Adebayo, M.A. (2012). Challenges Facing Sustainable Real Estate Marketing and Practice in Emerging Economy: Case Study of Nigeria. International Journal of Marketing Studies, 4(1), 58-67

Oni, A. O. (2010). Challenges Facing Estate Surveying and Valuation Profession on the Global Setting. Paper delivered at the Education Seminar Organized by African Real Estate Society (West Africa Group) held at the Centre for Learning Resources, Covenant University, Ota, Nigeria on 26th to 28th July 2010.

Oni, O. (2009). Real Estate Marketing and Code of Conduct in Nigeria. Lagos: Rehoboth Consulting. ISBN:978978-903-904-3, $222-232$. 